\title{
Influences of Dietary Supplementation of Chlorella vulgaris and Spirulina platensis on Growth-Related Genes Expression and Antioxidant Enzymes in Oreochromis niloticus Fish Exposed to Heavy Metals
}

\author{
Hassnaa Ahmed Saleh ${ }^{1, *}\left(\mathbb{D}\right.$, Hanan Sayed Gaber ${ }^{(\mathbb{D}}$, Hanaa Mahmoud Mohamed \\ El- Khayat $^{1}{ }^{(\mathbb{D}}$, Asmaa Abdel-Motleb ${ }^{1}{ }^{(\mathbb{D}}$, Wafaa Abdel-Aziz Mohammed ${ }^{1}{ }^{(\mathbb{D}}$, Hend \\ Okasha $^{3}$
}

${ }^{1}$ Theodor Bilharz Research Institute, Environmental Research and Medical Malacology Division, Imbaba, Giza 12411, Egypt.

${ }^{2}$ National Institute of Oceangraphy and Fisheris, Cairo, Egypt.

${ }^{3}$ Theodor Bilharz Research Institute, Biochemistry and Molecular Biology Department, Giza, Egypt.

\section{How to cite}

Saleh, H.A., Gaber, H.S., El-Khayat, H.M.M., Abdel-Motleb, A., Mohammed, W.A., Okasha, H. (2022). Influences of Dietary Supplementation of Chlorella vulgaris and Spirulina platensis on Growth-Related Genes Expression and Antioxidant Enzymes in Oreochromis niloticus Fish Exposed to Heavy Metals. Aquaculture Studies, 22(2), AQUAST793. http://doi.org/10.4194/AQUAST793

\section{Article History}

Received 07 October 2021

Accepted 09 December 2021

First Online 10 December 2021

\section{Corresponding Author}

Tel.: +20235407276

E-mail: a_hassnaa@yahoo.com

\section{Keywords}

Microalgae

Nile tilapia

Heavy metals

Gene expression

Oxidative stress

\begin{abstract}
Fish is a good indicator for monitoring of heavy metals risks. The present study was conducted to evaluate the effects of Chlorella vulgaris and Spirulina platensis dietary supplementation on Oreochromis niloticus growth under normal conditions. Additionally, evaluation of their effects on the growth performance, growth-related genes expression and antioxidant enzymes of $O$. niloticus exposed to a mixture of heavy metals. The results showed that the highest growth performance of $O$. niloticus was recorded in the groups supplemented with 10 and $15 \%$ of S. platensis compared to $C$. vulgaris and control groups. The expression of ghrelin, leptin and insulin-like growth factor genes (IGF-1) were improved in fish that fed on $10 \%$ and $15 \%$ of S. platensis more than $C$. vulgaris against the toxic impact of heavy metals. $15 \%$ of C. vulgaris improved the activity of catalase (CAT), while the activity of superoxide dismutases (SOD) was improved at $10 \%$ of both C. vulgaris and S. platensis. C. vulgaris and S. platensis increased glutathione peroxidase (GPx) activity compared to the normality. Our results concluded that $S$. platensis can effectively provide a protection in terms of growth-related genes expression in $O$. niloticus. Further, both $C$. vulgaris and $S$. platensis modulated heavy metals-induced oxidative stress.
\end{abstract}

\section{Introduction}

Fish is considered as an affordable source animal protein which implicates in the continuous improvement of human health (Balami et al., 2019). Tilapia fish is the most suitable species for aquaculture due to its relatively fast growth, easy breeding, adaptability to various environmental conditions and high diseases resistance (Prabu et al., 2020). Aquaculture production of tilapia fish has been significantly introduced in several tropical and subtropical countries during the second half of $20^{\text {th }}$ century (Al-Zayat, 2019). Nile tilapia (O. niloticus) which belongs to Cichlid family is an economically important freshwater fish in Egypt (Rafael et al., 2018). Egyptian aquaculture relies mainly on agricultural drainage water which may contain dangerous chemicals such as pesticides and heavy metals that threat the environmental protection and hinder the sustainable development of aquaculture (Han et al., 2019). Heavy 
metals are among the chemicals that originate from different types of agricultural wastes due to leaching of metals and soil erosion (Ali et al., 2019). Common toxic heavy metals in aquatic environments are lead $(\mathrm{Pb})$, mercury $(\mathrm{Hg})$, cadmium $(\mathrm{Cd})$, chromium $(\mathrm{Cr})$, arsenic (As), copper (Cu) and zinc (Zn) (Alalwan et al., 2020). Further, heavy metals are metallic chemical elements which have a relatively high density, and they are poisonous at even low concentration (Kumar et al., 2015).

Lead is one of the toxic heavy metals which its toxicity may be relatively high compared to the other essential metals (Zhiyou et al., 2016). Copper is a necessary trace metal for the growth and metabolism of living organisms and it may become toxic at high concentrations (Padrilah et al., 2018). Zinc is considered an essential micronutrient for growth, development and other processes of living organisms (Sharma et al., 2013). However, continuous accumulation of zinc in water becomes hazardous to aquatic organisms especially fish (Rajeshkumar \& Li, 2018). Fish is an important indicator to assess the deleterious effects of heavy metals in aquatic environments (Lee et al., 2019). Several studies demonstrated the deleterious effects of heavy metals on fish such as hampering physiological functions, immunotoxicity and genotoxicity (Cobbina et al., 2015). Heavy metals caused a variety of metabolic, physiological and histological changes in fish by altering various enzymes and metabolites (Mehmood et al., 2019). The toxic effects of heavy metals on antioxidant defense system, respiratory, digestive, excretory, reproductive and nervous system of fish had also been investigated (Javed \& Usmani, 2019).

Recently, the cost of fish commercial feeds increased continuously. Thus, it is necessary to find alternative feed sources and to make a stable supply for commercial diets (Hua et al., 2019). Algae have gained a great attention as alternative protein sources in fish culture (Roy \& Pal, 2014). Radhakrishnan et al. (2017) reported that algae are a diverse group of photosynthetic organisms which categorized as macroalgae and microalgae. Microalgae can be used as alternative protein sources which replace fishmeal and they can ensure sustainability standards in aquaculture (Shah et al., 2018). Microalgae can be grown in different environmental conditions due to their very limited growth requirements and high adaptability (Benedetti et al., 2018). C. vulgaris is a unicellular freshwater microalga that following Chlorophyta, Chlorophyceae (Shams et al., 2019). It contains high levels of proteins (51-58\%), vitamins, pigments and many essential amino acids (Khani et al., 2017, Andrade et al., 2018). Although C. vulgaris is previously employed as a dietary supplement of fish, but its ability to absorb metal ions from aqueous solutions is recently documented (Goher et al., 2016).

Additionally, S. platensis is a photosynthetic filamentous freshwater microalga classified as cyanobacterium and it is following class Cyanophyceae, order Nostocales (Andrade et al., 2018). It contains high levels of digestible protein (60-70\%), vitamins, minerals, essential amino acids, polyunsaturated fatty acids such as $\mathrm{\gamma}$-linolenic acid and various photosynthetic pigments (Simanjuntak et al., 2018). Nowadays, S. platensis is considered a good source of energy that can be used as an essential component in human and animal food (Jung et al., 2019). Moreover, it has been used for enhancing the growth parameters and disease resistance in fish (Sheikhzadeh et al., 2019). In fact, S. platensis has a high ability to adsorb heavy metals from aquatic environments (Budi et al., 2020). Consequently, it can be used in treatment of fish farming wastewater (Nogueira et al., 2018). The present study was conducted to evaluate the effects of dietary supplementation of C. vulgaris and S. platensis on the growth performance of $O$. niloticus fish under normal conditions. Also, their effects were investigated on the growth performance, growth-related genes expression and antioxidant enzymes of $O$. niloticus exposed to a mixture of heavy metals (Pb, Cu \& Zn).

\section{Materials and Methods}

\section{Experimental Fish}

The experimental fish (500 fish) with an average initial body weight $(30 \pm 2 \mathrm{~g})$ were purchased from a private fish farm in Giza governorate. Fish were transported to Environmental Research Department, Theodor Bilharz Research Institute, Giza, Egypt. The transportation of fish was made in polyethylene bags with aerated water. Fish were individually examined and proved to be free from any skin lesions particularly basis of pectoral and pelvic fins or physical damage. Fish were kept in 20 glass aquaria (60L) with dimensions of $70 \times 50$ $x 60 \mathrm{~cm}$ ( $25 \mathrm{fish} /$ aquarium) and filled with dechlorinated tap water $(48 \mathrm{~h})$. The aquaria were provided with a continuous aeration by air pumps. The fish were acclimated to the laboratory conditions for two weeks and fed twice daily with a commercial fish feed (35\% protein) before starting the experiments. During the acclimation period, the water quality parameters were as follows: water temperature $\left(25^{\circ} \mathrm{C}\right)$, dissolved oxygen $(5.38 \pm 0.25 \mathrm{mg} / \mathrm{L}), \mathrm{pH}(7.25 \pm 0.04)$, electrical conductivity $(418 \pm 6 \mu \mathrm{S} / \mathrm{cm})$ and total dissolved solids $(291 \pm 4 \mathrm{mg} / \mathrm{L})$. The water quality parameters were measured using portable meters (Hanna instruments Inc., RI, USA) followed the OECD guideline (OECD, 2012).

\section{Experimental Diets Preparation}

Dried C. vulgaris was purchased from commercial algae culture in Menoufia governorate, Egypt. $S$. platensis was produced by Spiro Tec Company in Egypt. The chemical and proximate composition of the basal feed and six experimental diets were analyzed for dry matter, crude protein, crude lipid, crude fiber, ash, moisture and carbohydrates according to standard 
methods (AOAC, 1992) by Chemistry Department, Animal Health Institute, Agriculture Research Centre (ARC), Dokki, Giza, Egypt. The experimental diets were prepared by mixing the basal feed with $C$. vulgaris and $S$. platensis at levels of $5 \%, 10 \%$ and $15 \%$ for each. Diets were mixed thoroughly with $100 \mathrm{ml}$ water for $1 \mathrm{~kg}$ and pelletized. After that, the pellets were air-dried at room temperature $\left(27^{\circ} \mathrm{C}\right)$ for $48 \mathrm{~h}$ and stored in a refrigerator at $4^{\circ} \mathrm{C}$ until use. Two experiments were employed to evaluate the effects of $C$. vulgaris and $S$. platensis on the growth performance under normal conditions and tolerance of $O$. niloticus fish to heavy metals toxicity.

\section{Experiment (1): Effect of $C$. vulgaris and S. platensis on the Growth Performance of $O$. niloticus}

At the beginning of the experiment, a total of 210 fish were used with an average initial body weight $(30.5 \pm 1.20 \mathrm{~g})$. The experiment included seven fish groups each consisted of 30 fish. Six experimental diets were formulated using the basal feed supplemented with three levels $(5 \%, 10 \%$ and $15 \%)$ from each of C. vulgaris (CL) and S. platensis (SP). The seventh group was the basal feed without microalgae as a control. The experiment was carried out in 21 glass aquaria of the dimensions; $70 \times 50 \times 60 \mathrm{~cm}$ and supplied with a total volume of $35 \mathrm{~L}$ of dechlorinated tap water $(48 \mathrm{~h})$. Three aquaria were assigned for each group (10 fish/ aquarium) and provided with continuous aeration by air pumps. The feed diets were supplied for 7 days per week and fish were fed twice a day, 9:00 am and 3:00 pm. Fish feces and feed residues were removed daily by siphoning, while the water in each aquarium was changed once every week. Fish in each aquarium were collectively weighed and counted every week throughout the experimental period ( 8 weeks). The feed consumption for each diet was readjusted weekly according to the new fish biomass as $3 \%$ of live body weight from the diet which was formulated requirements according to NRC (1993). During the experimental period, the water quality parameters were as follows: water temperature $\left(25 \pm 1^{\circ} \mathrm{C}\right)$, dissolved oxygen was from 5.42 to $6.57 \mathrm{mg} / \mathrm{L}$, $\mathrm{pH}$ was from 7.28 to 7.52 , electrical conductivity was from 423 to 511 $\mu \mathrm{S} / \mathrm{cm}$ and total dissolved solids was from 294 to 357 $\mathrm{mg} / \mathrm{L}$.

\section{Determination of Growth Parameters}

Average body weight $(\mathrm{g})$ for all fish per treatment was measured every week. At the end of the feeding trial, all fish were counted and weighed for calculation the growth parameters according to the following equations:

Weight gain (WG) = average final weight (g) - average initial weight (g) (Bekcan et al., 2006).
Average daily gain (ADG) = weight gain $(\mathrm{g}) /$ experimental period (days) (Castell \& Tiews, 1980).

Specific growth rate $(S G R)=(L n$. final body weight - Ln . initial body weight) $\times 100$ /experimental period (days)

(Bekcan et al., 2006).

Relative weight gain (RWG) = weight gain/initial weight x 100 (Brown, 1957).

Feed conversion ratio (FCR) = dry feed fed in g/wet weight gain (g) (Bekcan et al., 2006).

Survival rate $(S R)=$ the final number of fish - the initial number of fish $x 100$ (Bekcan et al., 2006).

Experiment (2): Effect of $C$. vulgaris and S. platensis on the Growth Performance, Expression of Growthrelated Genes and Antioxidant Enzymes of O. niloticus Fish Exposed to a Mixture of Heavy Metals

\section{Toxicity Bioassay}

Preliminary experiments: Preliminary experiments were conducted to determine the lethal and sub-lethal concentrations of $\mathrm{Pb}\left(\mathrm{NO}_{3}\right)_{2}, \mathrm{CuSO}_{4} .5 \mathrm{H}_{2} \mathrm{O}$ and $\mathrm{ZnSO}_{4} .7 \mathrm{H}_{2} \mathrm{O}$ after $96 \mathrm{~h}$ (APHA, 2005) against healthy specimens of $O$. niloticus that having an average body weight of $32.8 \pm 1.48 \mathrm{~g}$ without feeding. The sub-lethal concentration ( $\mathrm{LC}_{5}$ ) of $\mathrm{Pb}, \mathrm{Cu}$ and $\mathrm{Zn}$ was estimated at $1.1,0.44$ and $5.9 \mathrm{mg} / \mathrm{L}$, respectively by probit analysis according to the method of American Public Health Association (APHA, 2005) using SPSS computer program (version 17).

Chronic exposure: The present experiment explored the chronic exposure of 180 healthy specimens of $O$. niloticus that having the previous same body weight and divided into six groups for a period of five weeks. The first four groups were fed on diets that formulated using the basal feed in addition to $C$. vulgaris and S. platensis each at levels of 10\% and 15\%, (CL10 \& CL15 and SP10 \& SP15) with a mixture of heavy metals at concentrations of $1 / 5 \mathrm{LC}_{5}$ of each of $\mathrm{Pb}, \mathrm{Cu}$ and $\mathrm{Zn}$. The fifth group was fed only on the basal feed as a control (BF-HMs). The sixth group was fed on the basal feed with a mixture of heavy metals (BF+HMs). Three aquaria were assigned for each group (10 fish/ aquarium). Fish were exposed to the sub-lethal concentrations of the tested chemicals in $35 \mathrm{~L}$ of dechlorinated tap water. The feed diets were supplied for 7 days per week and fish were fed twice a day, 9:00 am and 3:00 pm. At the end of the experiment, the growth parameters were calculated according to the equations mentioned above. As well, the specimens of stomach, intestine and liver of fish were taken for assessing the growth-related genes expression. In addition to, specimens of liver was only taken to assay the activities of antioxidant enzymes. During the experimental period, the water quality parameters were 
as follows: water temperature $\left(25 \pm 1^{\circ} \mathrm{C}\right)$, dissolved oxygen was from 4.93 to $6.14 \mathrm{mg} / \mathrm{L}, \mathrm{pH}$ was from 7.32 to 7.81 , electrical conductivity was from 434 to 537 $\mu \mathrm{S} / \mathrm{cm}$ and total dissolved solids was from 296 to 386 $\mathrm{mg} / \mathrm{L}$.

\section{Relative Expression of Growth-related Genes}

Stomach, intestine and liver tissues were separated from all fish groups at the end of the experiment. $50 \mathrm{mg}$ of each organ was homogenized in iced tubes using a motor homogenizer. Total RNA was isolated from the homogenized tissues with a total RNA purification kit provided by Jena Bioscience (Munich, Germany) and stored at $-80^{\circ} \mathrm{C}$. RNA was converted into its complementary DNA by a cDNA synthesis kit (Applied Biosystems, Foster City, California, USA). Quantitative PCR (qPCR) was performed using the GoTaq PCR master mix (Promega Co., Madison, USA). A protocol that included an initial denaturation step was performed at $95^{\circ} \mathrm{C}$ for 10 minutes, followed by 40 cycles of denaturing at $95^{\circ} \mathrm{C}$ for $15 \mathrm{~s}$. Thereafter, annealing and extension was performed at $60^{\circ} \mathrm{C}$ for 1 minute, and then $60^{\circ} \mathrm{C}$ for $30 \mathrm{~s}$ on a Step One Real-Time PCR System (Applied Biosystems, Foster City, California, USA). Table 1 showed the sequence $\left(5^{\prime} \rightarrow 3^{\prime}\right)$ of oligonucleotide primers and $\beta$ actin as an internal control for normalization of target genes (ghrelin, leptin and IGF-1) according to $2^{-\Delta \Delta c t}$ method (Amin et al., 2019).

\section{Assay of Antioxidant Enzymes Activity}

Antioxidant enzymes such as CAT, GPx and SOD were assayed in liver extracts which prepared from the six fish groups. The collected livers were washed in an ice-cold (1.15\% KCL solution), blotted, and weighed. They were then homogenized in potassium phosphate buffer ( $\mathrm{pH} 7)$ at a ratio of $1 \mathrm{~g}$ : $7 \mathrm{ml}$. Thereafter, they were homogenized by electrical mortar in iced tubes and centrifuged at $14000 \mathrm{rpm}$ speed for $15 \mathrm{~min}$ at $4^{\circ} \mathrm{C}$. The supernatants were obtained and analyzed on the same day using semi-automated Clinical Chemistry analyzer for the enzymes (TEMIS instrument, Spain). The activities of CAT, GPx and SOD were assayed using Commercial Diagnostic Kits (Biodiagnostic Company, Giza, Egypt). The activity of CAT was measured using the method of Aebi (1984). GPx activity was estimated accordingly to Paglia \& Valentine (1967). SOD activity was measured in accordance to the method of Nishikimi et al. (1972).

\section{Statistical Analysis}

The data were presented as mean \pm standard deviation (SD) of at least three replicates. The one-way and two-way analysis of variance (ANOVA) and Tukey test were used to assess the statistically significant differences between the means. The tests were performed using SPSS program version 17 (SPSS, Inc., Chicago, IL) for Windows.

\section{Results}

\section{Chemical Composition of the Experimental Diets}

In the present study, six experimental diets were evaluated and compared to the control group which supplied by the commercial fish feed. Commercial fish feed was supplemented with $C$. vulgaris and S. platensis separately at various levels $(5 \% \mathrm{CL}, 10 \% \mathrm{CL}, 15 \% \mathrm{CL}, 5 \%$ SP, $10 \%$ SP and $15 \%$ SP). The chemical composition of the basal fish feed and the experimental diets are presented in Table 2. The results of the proximate composition of the basal fish feed and the experimental diets are shown in Table 3. Protein level increased in the dietary groups than that of control (35\%) by increasing the level of the microalgae. The highest levels were recorded with 10 and 15\% SP (38.9 and 39.6\%, respectively). The least levels of crude lipid were recorded with 10 and 15\% SP (4.53 and $4.38 \%$, respectively). Also, 10 and $15 \%$ SP showed the least ash contents (5.7 and 5.3\%, respectively). Moisture gradually decreased in all dietary groups than control $(5.2 \%)$ by increasing microalgae (\%). Within each dietary group, the gross energy increased by the increasing $\%$ of microalgae. Each of dry matter, crude fiber (\%) and carbohydrate showed approximately the same levels as the control group.

\section{Determination of Growth Parameters}

The results of the first experiment indicated that fish fed on $10 \%$ and $15 \% \mathrm{CL}$ recorded the most significant differences with the control group at $\mathrm{P}<0.05$ after 8 weeks of feeding. However, the highest value for average final body weight was observed in feed that impregnated with $15 \% \mathrm{CL}(67.3 \pm 2.39 \mathrm{~g})$ (Figure 1). The results of average body weight of fish that fed on various levels of S. platensis for 8 weeks are shown in Figure 2. Final body weight was significantly higher with supplementation of $5 \%, 10 \%$ and $15 \%$ SP than the

Table 1. Sequence of oligonucleotide primers used for the quantification of the mRNA expression by qPCR

\begin{tabular}{lccccc}
\hline & & \multicolumn{2}{c}{ Oligonucleotide primers, Sequence $\left(5^{\prime} \rightarrow 3^{\prime}\right)$} & & \\
\cline { 3 - 4 } Genes & Organs & Sense & Antisense & Accession number & References \\
\hline Ghrelin & Stomach & GTGGTGCAAGTCAACCAGTG & CATGGCTTGGCGACCAATTC & XM_003441463.5 & (Amin et al., 2019) \\
Leptin & Intestine & AGTCACTATAAGCCCGACAG & GCCATTCCAAGATCATAAGGT & XM_003440570.5 & (Liu et al., 2018) \\
IGF-1 & Liver & GTGGTGCAAGTCAACCAGTG & GAAGCAGCACTCGTCCACG & XM_019346352.2 & (Amin et al., 2019) \\
B-actin & Internal control & TGGCATCACACCTTCTATAACGA & TGGCAGGAGTGTTGAAGGTCT & XM_003444484.4 & (Amin et al., 2019) \\
\hline
\end{tabular}


Table 2. Chemical composition of the basal fish feed and the experimental diets $\left(\mathrm{g} \mathrm{kg}^{-1}\right)$.

\begin{tabular}{lccccccc}
\hline Feed ingredients & \multicolumn{5}{c}{ Dietary groups } \\
\cline { 2 - 7 } & Control & $5 \% \mathrm{CL}$ & $10 \% \mathrm{CL}$ & $15 \% \mathrm{CL}$ & $5 \%$ SP & $10 \%$ SP & $15 \% \mathrm{SP}$ \\
\hline Fishmeal (60 \%) & 25 & 23.75 & 22.5 & 21.25 & 23.75 & 22.5 & 21.25 \\
Soybean Meal (48 \%) & 34 & 34 & 34 & 34 & 34 & 34 & 34 \\
Wheat bran (60 \%) & 10 & 10 & 10 & 10 & 10 & 10 & 10 \\
Yellow Corn (48 \%) & 24 & 24 & 24 & 24 & 24 & 24 & 24 \\
Corn gulten & 6 & 6 & 6 & 6 & 6 & 6 & 6 \\
C. vulgaris & - & 1.25 & 2.5 & 3.75 & - & - & - \\
S. platensis & - & - & - & - & 1.25 & 2.5 & 3.75 \\
Vitamins and minerals mixture & 1 & 1 & 1 & 1 & 1 & 1 & 1 \\
\hline
\end{tabular}

Table 3. Proximate composition of the basal fish feed and the experimental diets (\% dry weights).

\begin{tabular}{|c|c|c|c|c|c|c|c|}
\hline \multirow[t]{2}{*}{ Proximate composition } & \multicolumn{7}{|c|}{ Experimental Diets } \\
\hline & Control & $5 \% \mathrm{CL}$ & $10 \% \mathrm{CL}$ & $15 \% \mathrm{CL}$ & $5 \% \mathrm{SP}$ & $10 \% \mathrm{SP}$ & $15 \% \mathrm{SP}$ \\
\hline Dry matter (DM) & 91.3 & 91.39 & 91.55 & 91.75 & 92.6 & 92.7 & 92.9 \\
\hline Crude protein (\%) & 35 & 35.7 & 36.2 & 37 & 38.2 & 38.9 & 39.6 \\
\hline Crude lipid (\%) & 5,8 & 5,72 & 5,50 & 4,65 & 4,57 & 4,53 & 4,38 \\
\hline Crude fiber (\%) & 3,50 & 3,51 & 3,55 & 3,60 & 3,55 & 3,60 & 3,65 \\
\hline Ash (\%) & 6,3 & 7,9 & 7,3 & 6,8 & 6,4 & 5,7 & 5,3 \\
\hline Moisture & 5,20 & 5,10 & 4,90 & 4,65 & 3,85 & 3,70 & 3,45 \\
\hline Carbohydrates $^{1}$ & 44.2 & 42.07 & 42.55 & 43.3 & 43.43 & 43.57 & 43.62 \\
\hline Gross energy (Kcal/Kg) & 4100 & 3110 & 3222 & 3289 & 3394 & 3433 & 3535 \\
\hline
\end{tabular}

${ }^{1}$ Carbohydrates calculated as the difference $\%$ DM - (\% protein + \% lipid + \% Ash).

${ }^{*}$ Chemical composition of S. platensis: Crude protein - 60.43\%; Crude lipid - 6.16\%; Total carbohydrate - 13.21; Fiber - 3.32\%; Ash - 10.55\%; Dry matter - 93.67; Moisture 6.33\%. *Chemical composition of C. vulgaris: Crude protein - 51.1\%; Crude lipid - 7.5\%; Total carbohydrate - 13.7; Fiber-9.6\%; Ash - 11.0\%; Dry matter-94.7; Moisture 5.3\%.

Table 4. Growth parameters of $O$. niloticus fed on the basal feed (control) and six experimental diets.

\begin{tabular}{lccccccc}
\hline & & \multicolumn{5}{c}{ Experimental diets } \\
\cline { 3 - 8 } Growth Parameters & Control & $5 \% \mathrm{CL}$ & $10 \% \mathrm{CL}$ & $15 \% \mathrm{CL}$ & $5 \% \mathrm{SP}$ & $10 \% \mathrm{SP}$ & $15 \% \mathrm{SP}$ \\
\hline Initial weight $(\mathrm{g})$ & $30.9^{\mathrm{a}} \pm 1.56$ & $30.8^{\mathrm{a}} \pm 1.35$ & $30.1^{\mathrm{a}} \pm 1.56$ & $30.5^{\mathrm{a}} \pm 1.22$ & $30.2^{\mathrm{a}} \pm 1.30$ & $30.6^{\mathrm{a}} \pm 1.25$ & $30.7^{\mathrm{a}} \pm 1.34$ \\
Final weight (g) & $61.4^{\mathrm{a}} \pm 2.21$ & $62.1^{\mathrm{a}} \pm 2.35$ & $65.8^{\mathrm{b}} \pm 2.26$ & $67.3^{\mathrm{b}} \pm 2.39$ & $69.5^{\mathrm{b}} \pm 2.45$ & $78.6^{\mathrm{c}} \pm 2.88$ & $79.8^{\mathrm{c}} \pm 3.07$ \\
WG (g) & $30.5^{\mathrm{a}} \pm 1.75$ & $31.3^{\mathrm{a}} \pm 1.81$ & $35.7^{\mathrm{a}} \pm 1.87$ & $36.8^{\mathrm{a}} \pm 1.48$ & $39.3^{\mathrm{b}} \pm 2.08$ & $48^{\mathrm{c}} \pm 1.95$ & $49.1^{\mathrm{c}} \pm 2.14$ \\
ADG (g/fish/day) & $0.54^{\mathrm{a}} \pm 0.01$ & $0.56^{\mathrm{a}} \pm 0.01$ & $0.64^{\mathrm{a}} \pm 0.04$ & $0.66^{\mathrm{a}} \pm 0.03$ & $0.70^{\mathrm{b}} \pm 0.02$ & $0.86^{\mathrm{c}} \pm 0.04$ & $0.88^{\mathrm{c}} \pm 0.03$ \\
SGR (\%/day) & $1.23^{\mathrm{a}} \pm 0.07$ & $1.25^{\mathrm{a}} \pm 0.05$ & $1.40^{\mathrm{a}} \pm 0.08$ & $1.41^{\mathrm{a}} \pm 0.04$ & $1.49^{\mathrm{b}} \pm 0.09$ & $1.68^{\mathrm{c} \pm 0.11}$ & $1.70^{\mathrm{c}} \pm 0.12$ \\
RWG (\%) & $98.71^{\mathrm{a}} \pm 3.94$ & $101.62^{\mathrm{a}} \pm 3.65$ & $118.60^{\mathrm{a}} \pm 3.81$ & $120.66^{\mathrm{a}} \pm 4.83$ & $130.13^{\mathrm{b}} \pm 6.05$ & $156.86^{\mathrm{c}} 5.89$ & $159.93^{\mathrm{c}} 6.42$ \\
FCR (g/fish) & $2.04^{\mathrm{a}} \pm 0.12$ & $2.01^{\mathrm{a}} \pm 0.12$ & $1.78^{\mathrm{b}} \pm 0.11$ & $1.75^{\mathrm{b}} \pm 0.10$ & $1.72^{\mathrm{b}} \pm 0.10$ & $1.58^{\mathrm{c} \pm 0.09}$ & $1.56^{\mathrm{c} \pm 0.09}$ \\
SR (\%) & 100 & 100 & 100 & 100 & 100 & 100 & 100 \\
\hline
\end{tabular}

* The values are presented as the mean of all samples in each group \pm SD. Means in the same row with different letters differ significantly ( $<0.05)$; while the same letters indicate non-significance. WG: weight gain; ADG: average daily gain; SGR: specific growth rate; RWG: relative weight gain; FCR: feed conversion ratio; SR \%: survival rate.

control group at $\mathrm{P}<0.05$ after 8 weeks of feeding. Furthermore, 15\% SP showed the highest value for average final body weight $(79.8 \pm 3.07 \mathrm{~g})$.

The results of the effect of $C$. vulgaris and S. platensis supplementation on the growth performance of $O$. niloticus under normal conditions are presented in Table 4. At the end of the feeding trial, fish that fed on $15 \%$ SP recorded a higher average weight gain $(49.1 \pm 2.14 \mathrm{~g})$, average daily gain $(0.88 \pm 0.03$ $\mathrm{g} /$ fish/day), specific growth rate $(1.70 \pm 0.12 \% /$ day $)$ and a relative weight gain $(159.93 \pm 6.42 \%)$ than fish fed on the rest of the experimental diets and control group at $\mathrm{P}<0.05$. In addition, fish that fed on $10 \%$ and $15 \%$ SP had lower feed conversion ratios $(0.049 \pm 0.00 \mathrm{~g} / \mathrm{fish})$ than fish fed on the other diets and control group at $\mathrm{P}<0.05$.
Moreover, the survival rates of $O$. niloticus fish were the same for all the experimental diets and control group, $100 \%$.

Growth performance of $O$. niloticus exposed to heavy metals and fed on diets enriched with two levels of $C$. vulgaris and S. platensis are presented in Table 5. The exposure of $O$. niloticus to heavy metals ( $\mathrm{FF}+\mathrm{HMs}$ ) significantly reduced the survival rate and growth parameters compared to control (BF-HMs) at $P<0.05$. On the other hand, $C$. vulgaris and $S$. platensis improved the survival rate and growth parameters in exposed fish to heavy metals. Moreover, the highest values of WG, ADG, SGR and RWG were recorded with SP15+HMs $(20.1 \pm 1.19 \mathrm{~g}, 0.57 \pm 0.01 \mathrm{~g} /$ fish/day, $1.38 \pm 0.10 \% /$ day and $61.85 \pm 2.91 \%$, respectively) compared to the other 


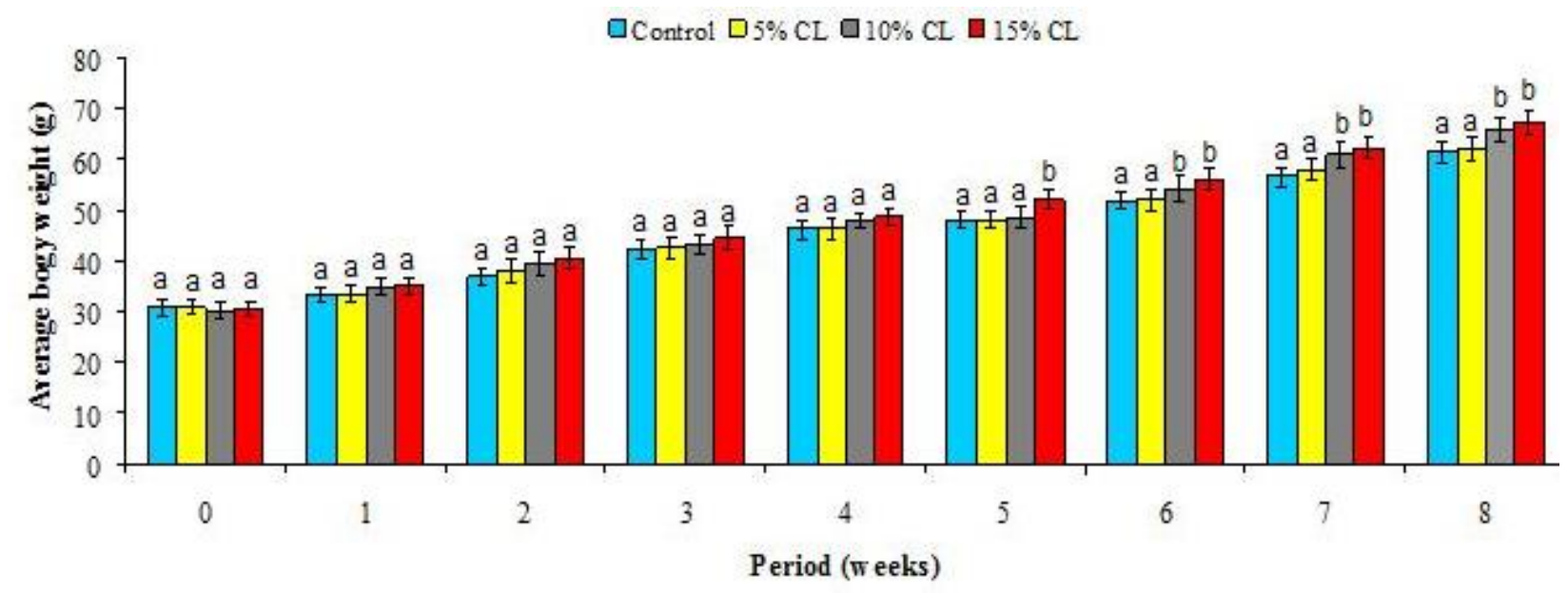

Figure 1. Average body weight (g) of $O$. niloticus fed on various levels of $C$. vulgaris (CL) for 8 weeks.

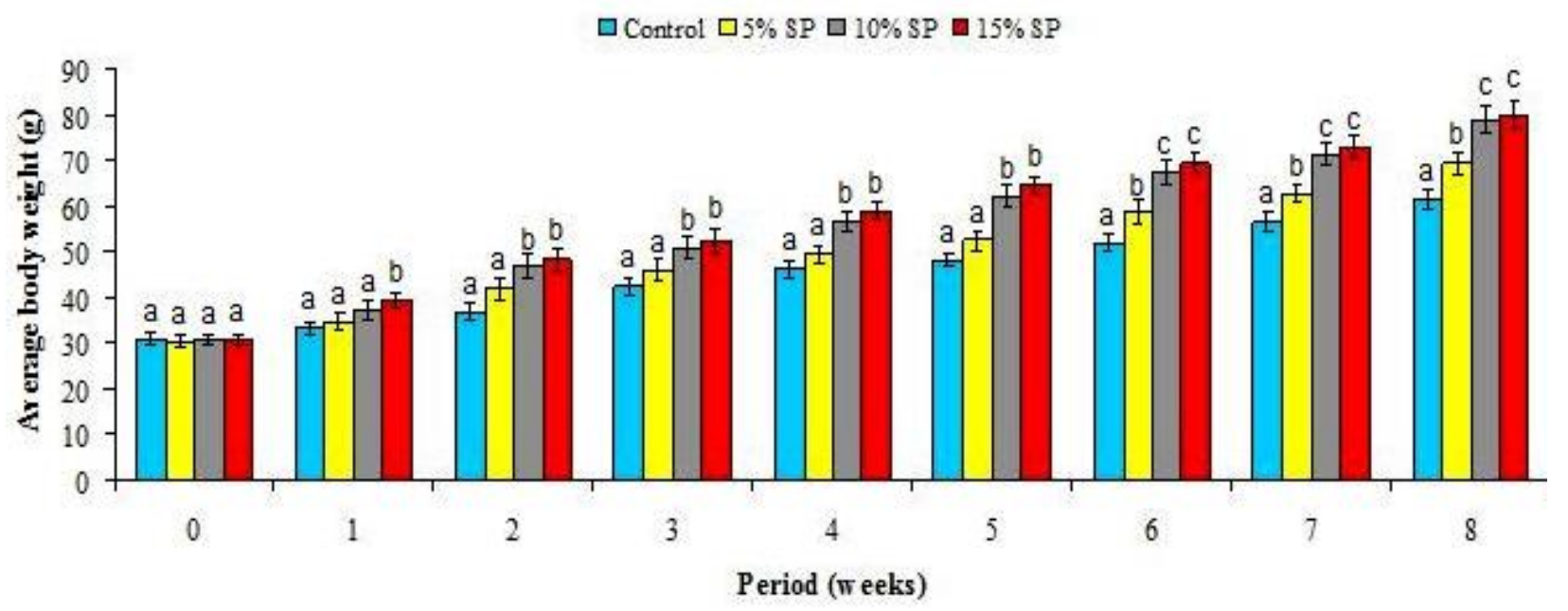

Figure 2. Average body weight (g) of $O$. niloticus fed on various levels of $S$. platensis (SP) for 8 weeks.

groups. Regarding FCR, it was observed a significant increase in FCR value with heavy metals (BF+HMs). On the contrary, the highest decrease in FCR was found in those fish fed SP15+HMs $(1.86 \pm 0.10 \mathrm{~g} /$ fish $)$ compared to the other groups. No statistically significant variations were detected on the SR value of fish fed S. platensis supplemented diets, respect to the value found in fish fed control (BF-HMs).

\section{Relative Expression of Growth-related Genes}

The results of figure 3 showed that ghrelin, leptin and IGF-1 expressions were significantly difference when comparing the interaction between the groups and the relative gene expression values ( $P$-value= 0.039). The presence of $C$. vulgaris did not affect on the expression of ghrelin in the stomach. However, the leptin expression in the intestine increased by the treatment with $\mathrm{CL} 15+\mathrm{HMs}$ group compared to $\mathrm{BF}+\mathrm{HMs}$ group. IGF-1 expression in the liver was improved by both treatments ( $\mathrm{CL} 10+\mathrm{HMs} \& \mathrm{CL} 15+\mathrm{HMs}$ ) compared to $\mathrm{BF}+\mathrm{HMs}$ group. The results of figure 4 showed that ghrelin, leptin and IGF-1 expressions were significantly difference when comparing the interaction between the groups and the relative gene expression values ( $P$ value $=0.044)$. The results showed that SP10+HMs \& SP15+HMs, successively improved the expression of ghrelin, leptin and IGF-1 compared to BF+HMs group. Overall, our study indicated that the addition of S. platensis improved all growth-related genes expression in the presence of heavy metals mixture more than C. vulgaris.

\section{Assay of Antioxidant Enzymes Activity}

In the present study, CAT, GPx and SOD activities in the liver of $O$. niloticus fish that exposed to heavy metals were measured within the different treated groups (Figure 5). The results illustrated that $\mathrm{BF}+\mathrm{HMs}$ group showed a significant decrease in CAT and GPx activities compared to the control group (BF-HMs) at $\mathrm{P}<0.05$. However, CL15\%+HMs group significantly increased CAT activity compared to the other treated groups. All treated groups showed a significant increase $(P<0.05)$ in GPx more than the normal (BF-HMs), especially SP10+HMs group that showed the most significant 
Table 5. Growth parameters of $O$. niloticus exposed to heavy metals and fed on diets enriched with two levels of $C$. vulgaris and S. platensis.

\begin{tabular}{lcccccc}
\hline & & & \multicolumn{4}{c}{ Experimental diets } \\
\cline { 4 - 7 } Growth Parameters & (BF-HMs) & $(B F+H M s)$ & $C L 10+H M s$ & $C L 15+H M s$ & SP10+HMs & SP15+HMs \\
\hline Initial weight (g) & $33.4^{\mathrm{a}} \pm 1.69$ & $32.1^{\mathrm{a}} \pm 1.28$ & $32.9^{\mathrm{a}} \pm 1.66$ & $33.2^{\mathrm{a}} \pm 1.58$ & $32.7^{\mathrm{a}} \pm 1.30$ & $32.5^{\mathrm{a}} \pm 1.38$ \\
Final weight (g) & $51.8^{\mathrm{a}} \pm 2.06$ & $34.1^{\mathrm{b}} \pm 1.36$ & $41.4^{\mathrm{c}} \pm 1.83$ & $47.3^{\mathrm{a}} \pm 1.79$ & $49.7^{\mathrm{a}} \pm 1.98$ & $52.6^{\mathrm{a}} \pm 2.31$ \\
WG (g) & $18.4^{\mathrm{a}} \pm 0.73$ & $2.0^{\mathrm{b}} \pm 0.11$ & $8.5^{\mathrm{c}} \pm 0.50$ & $14.1^{\mathrm{a}} \pm 0.82$ & $17.0^{\mathrm{a}} \pm 1.03$ & $20.1^{\mathrm{a}} \pm 1.19$ \\
ADG (g/fish/day) & $0.53^{\mathrm{a}} \pm 0.01$ & $0.06^{\mathrm{b}} \pm 0.00$ & $0.24^{\mathrm{c}} \pm 0.00$ & $0.40^{\mathrm{a}} \pm 0.01$ & $0.49^{\mathrm{a}} \pm 0.01$ & $0.57^{\mathrm{a}} \pm 0.01$ \\
SGR (\%/day) & $1.25^{\mathrm{a}} \pm 0.07$ & $0.17^{\mathrm{b}} \pm 0.00$ & $0.66^{\mathrm{c}} \pm 0.03$ & $1.01^{\mathrm{a}} \pm 0.06$ & $1.20^{\mathrm{a}} \pm 0.07$ & $1.38^{\mathrm{a}} \pm 0.10$ \\
RWG (\%) & $55.09^{\mathrm{a}} \pm 2.23$ & $6.23^{\mathrm{b}} \pm 0.29$ & $25.84^{\mathrm{c}} \pm 1.03$ & $42.47^{\mathrm{a}} \pm 1.69$ & $51.99^{\mathrm{a}} \pm 2.44$ & $61.85^{\mathrm{a}} \pm 2.91$ \\
FCR (g/fish) & $1.94^{\mathrm{a}} \pm 0.11$ & $14.45^{\mathrm{b}} \pm 0.85$ & $2.76^{\mathrm{c}} \pm 0.20$ & $2.21^{\mathrm{a}} \pm 0.16$ & $2.13^{\mathrm{a}} \pm 0.15$ & $1.86^{\mathrm{a}} \pm 0.10$ \\
SR (\%) & 100 & 40 & 80 & 90 & 100 & 100 \\
\hline
\end{tabular}

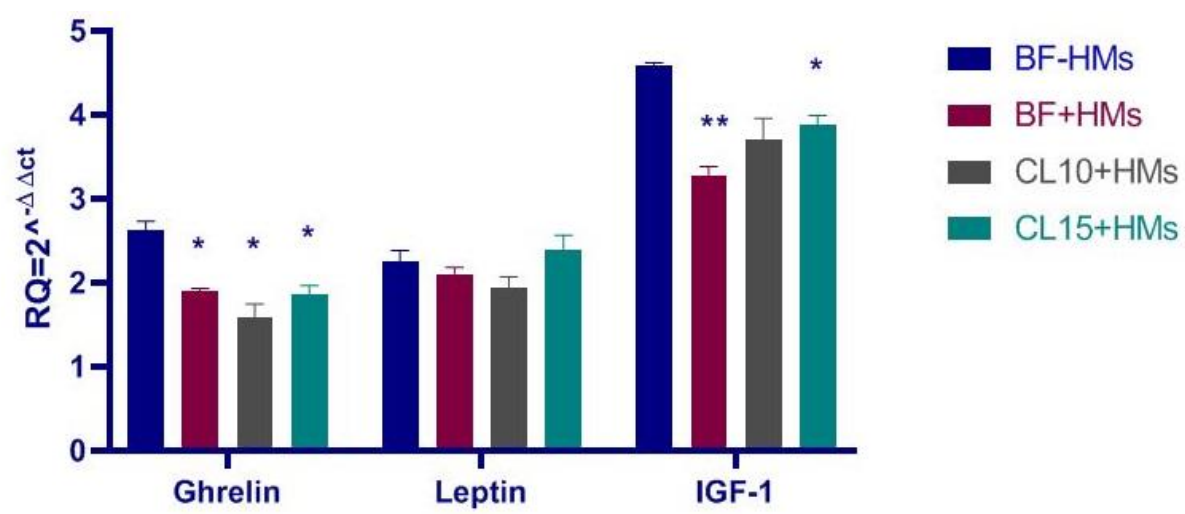

Figure 3. Relative expression of Ghrelin gene in the stomach, Leptin gene in the intestine and IGF-1 gene in liver of $O$. niloticus exposed to heavy metals and fed on diets enriched with two levels of $C$. vulgaris ( $P$-value $=0.039$ ).

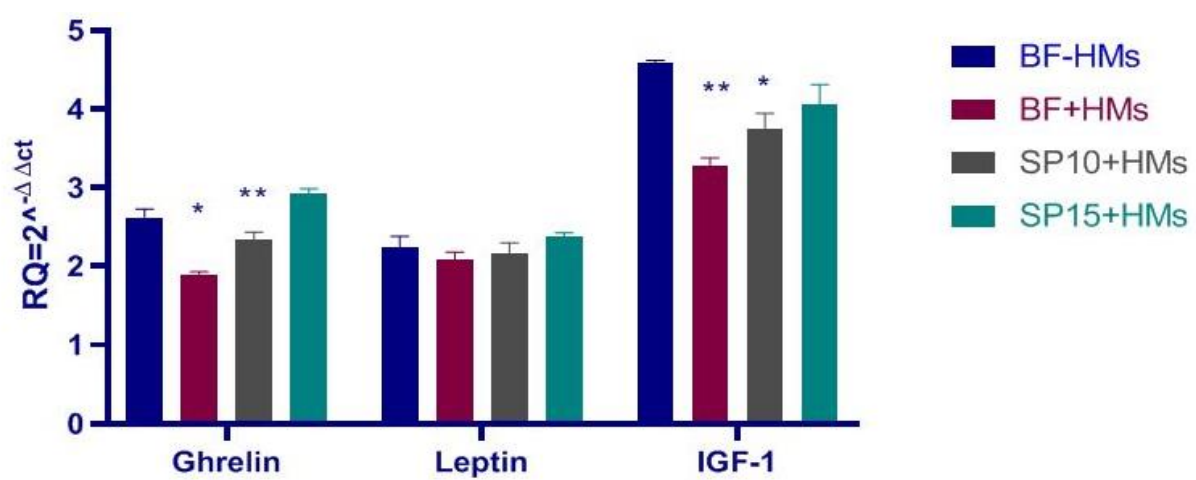

Figure 4. Relative expression of Ghrelin gene in the stomach, Leptin gene in the intestine and IGF-1 gene in liver of $O$. niloticus exposed to heavy metals and fed on diets enriched with two levels of $S$. platensis ( $P$-value $=0.044)$.

increase. Concerning SOD, BF+HMs group only showed a slight increase in the enzyme activity compared to the control group (BF-HMs), while CL10+HMs and SP10+HMs groups showed approximately normal levels.

\section{Discussion}

During the recent years, aquaculture directed toward the addition of an alternative protein source to fish feed (Dawood, 2017). Microalgae are as a promising alternative protein source for fish culture and to ensure sustainability standards in aquaculture. The first experiment in our study was conducted to evaluate the effect of microalgae; C. vulgaris and S. platensis supplementation on the growth performance of $O$. niloticus under normal conditions. C. vulgaris and S. platensis have bioactive compounds like proteins, polyunsaturated fatty acids, vitamins, sterols and other compounds that make those microalgae very interesting from the health benefits point of view (Abdulrahman et al., 2018; Andrade et al., 2018). The results of the present study indicated that the growth parameters of $O$. niloticus increased with increasing the levels of C. vulgaris in fish diets compared to the control group. With respect to Khani et al. (2017) who showed that dietary supplementation of $5 \%$ C. vulgaris significantly 
A

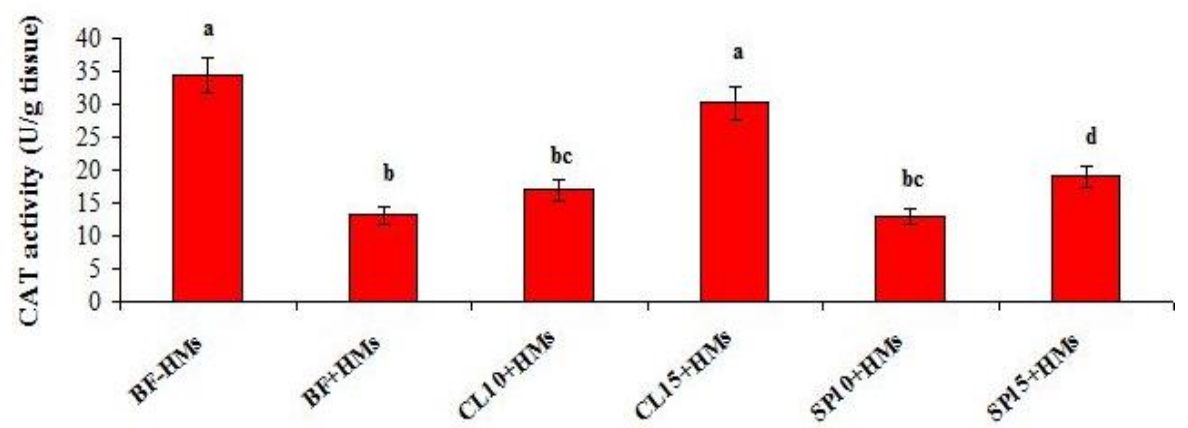

B

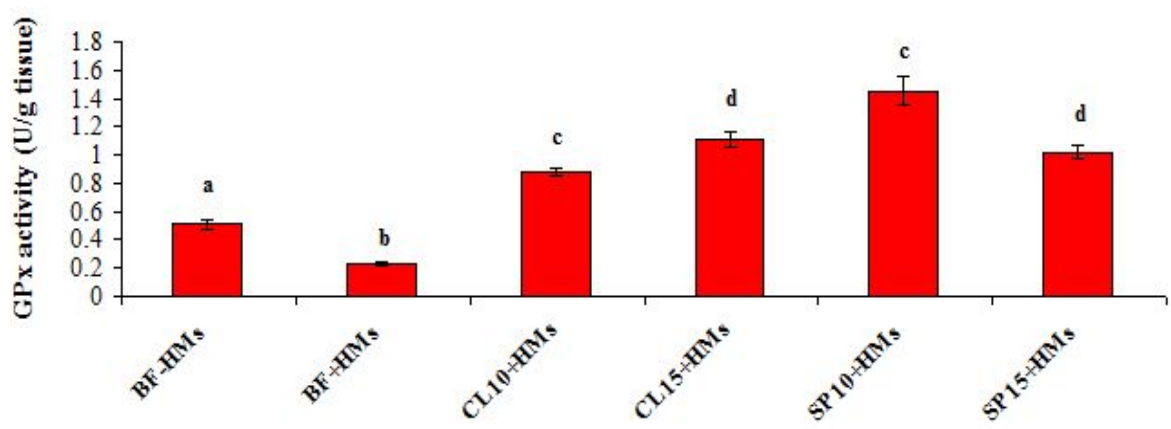

C

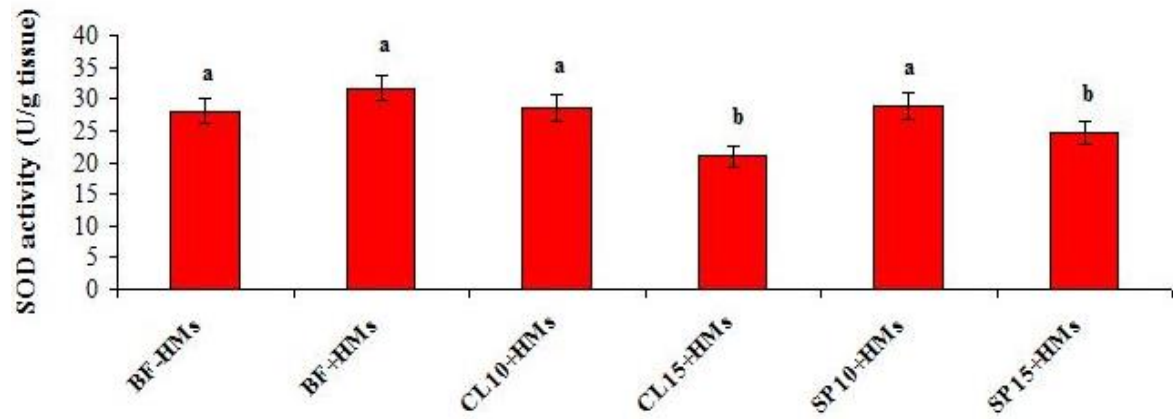

Figure 5. (A) Catalase (CAT), (B) glutathione peroxidase (GPx) and (C) superoxide dismutase (SOD) activities in liver of $O$. niloticus fish exposed to heavy metals and fed on diets enriched with two levels of $C$. vulgaris and S. platensis.

increased the growth of koi fish. The present study also indicated that $O$. niloticus fish had a higher body weight with supplementation of $5 \%, 10 \%$ and $15 \%$ S. platensis in fish diets than the control group. These results are in agreement with Simanjuntak et al. (2018) who reported that increasing levels of $S$. platensis supplementation in the diet followed by increased body weight of gurami (Osphronemus gouramy) compared to the control group.

The current study showed the highest values of weight gain, average daily gain, specific growth rate and relative weight gain of $O$. niloticus fish in the groups that supplemented with 10 and $15 \%$ S. platensis compared to C. vulgaris and control groups. These results are in accordance with a study conducted by Promya \& Chitmanat (2011) who found that a $10-15 \%$ replacement of crushed fish with Spirulina led to an increase of average daily growth rate and specific growth rate of
Red Tilapia. This finding is also similar to that reported by Teimouri et al. (2013) who found that replacement of fishmeal with S. platensis up to $10 \%$ increase the growth rate of rainbow trout. Mahmoud et al. (2018) also reported that the body weight, weight gain and specific growth rate of $O$. niloticus fish increased with the increasing of S. platensis levels in fish diets. Additionally, $10 \%$ and $15 \%$ S. platensis groups showed significant decrease in FCR than the control group and the other diets. Similar results were obtained by De Chavez \& Bolivar (2018) in Clarias gariepinus that fed on Spirulina. These results were reinforced by the proximate chemical composition analysis of $10 \%$ and $15 \%$ S. platensis since they characterized by highest protein $\%$ and the least percentage of crude lipid and ash as well. Ibrahem et al. (2013) stated that S. platensis supplementation in $O$. niloticus fish feed improved the feed conversion ratio and growth rates. Zeinab et al. 
(2015) stated that the best FCR values were observed in fish diets that supplemented with of S. platensis.

The second experiment was conducted to evaluate the effect of $C$. vulgaris and S. platensis on the growth performance, growth-related genes expression and antioxidant enzymes of $O$. niloticus fish exposed to heavy metals mixture ( $\mathrm{Pb}, \mathrm{Cu} \& \mathrm{Zn})$. Heavy metals are regarded as one of the most environmental problems that facing aquaculture in Egypt (El-Mezayen et al., 2018). Fish is a good indicator for monitoring the potential risks of heavy metals (Authman et al., 2015). The present study showed a reduction in the growth parameters of $O$. niloticus exposed to heavy metals. Heavy metals caused poor food conversion efficiency which lead to a reduction in the growth parameters. One of the most obvious signs of heavy metals toxicity in fish is growth inhibition (Zaynab et al., 2021). The results indicated that $C$. vulgaris improved the growth performance of $O$. niloticus exposed to heavy metals. These results are in agreement with Abdelhamid et al. (2020) who reported that C. vulgaris improved the growth performance of $O$. niloticus after diazinon toxicity. Similarly, the results revealed that $S$. platensis improved the growth performance of $O$. niloticus exposed to heavy metals. These results are in parallel with Abdel-Tawwab et al. (2021) who found that S. platensis supplementation improved the growth performance of $O$. niloticus exposed to imidacloprid insecticide.

To the best of our knowledge, this is the first study that was conducted to evaluate the effect of $C$. vulgaris and S. platensis on the expression of the growth-related genes; ghrelin, leptin and IGF-1 in $O$. niloticus fish exposed to heavy metals. The results revealed that the levels of ghrelin, leptin and IGF-1 expression in $O$. niloticus decreased with heavy metals compared to the control group. The results also indicated that the highest concentration of $C$. vulgaris improved the expressions of leptin and IGF-1 only in $O$. niloticus exposed to heavy metals. These results are in line with Zahran et al. (2020) who found that $C$. vulgaris was able to modulate the immune-related genes of $O$. niloticus exposed to chlorpyrifos. Interestingly, our results showed that $S$. platensis supplementation strongly improved the expression of all growth-related genes in $O$. niloticus exposed to heavy metals. The present findings are consistent with Mahmoud et al. (2018) who found that $S$. platenesis supplementation showed an upregulation of TNF- $\alpha$ gene expression in $O$. niloticus challenged with Pseudomonas fluorescens. According to Sayed et al. (2017), there is a little information on the role of $S$. platensis in reducing heavy metals genotoxicity and oxidative stress in fishes. This improvement subsequently induce fish heath improvement may be related to ghrelin that regulated energy balance through controlling different functions such as feed intake, metabolism and intestinal activity, leptin which maintains energy homeostasis by balancing feeding and energy expenditure and IGF-1 which is considered a central growth- regulatory system and can be affected by multiple factors, especially the nutritional state of the fish (Beckman, 2011, Jönsson, 2013; Won et al., 2016).

Antioxidant enzymes are considered a primary defense system against oxidative cell damage (Mohanty \& Samanta, 2018; Teimouri et al., 2019). Moreover, antioxidants are used as biochemical markers of oxidative stress (Sevcikova et al., 2011). Oxidative stress refers to the imbalance between the levels of reactive oxygen species (ROS) and antioxidant defenses (Tripathy, 2016). Heavy metals could generate excessive ROS in fish leading to cellular damage (Hamed et al., 2019). The current study indicated that CAT and GPx activities were significantly decreased in the liver of $O$. niloticus fish exposed to heavy metals. On the other hand, SOD activity was increased in the fish that exposed to heavy metals. Similar results were obtained by Nofal et al. (2019) who found that higher level of SOD and lower level of CAT activity were observed in the polluted area of the Manzala farm. In addition, Eyckmans et al. (2011) found that CAT and GPx activities were significantly reduced and this may be caused by the consuming higher ROS after continuous heavy metals exposure.

The present study revealed that GPx activity increased in $O$. niloticus fish that fed on $C$. vulgaris in the presence of heavy metals. Our findings were consistent with those of Zahran \& Risha (2014) who concluded that dietary supplementation of $C$. vulgaris increased GPx activity in $O$. niloticus exposed to arsenic toxicity. Likewise, S. platensis increased GPx activity in $O$. niloticus exposed to heavy metals. These results are parallel with the study of Abdel-Tawwab et al. (2021) who reported that $S$. platensis increased GPx activity in $O$. niloticus exposed to imidacloprid insecticide. Additionally, S. platensis improved SOD enzyme activity in $O$. niloticus exposed to heavy metals. These results are in accordance with those of Abdelkhalek et al. (2015) who indicated that $S$. platensis enhanced SOD activity in $O$. niloticus exposed to deltamethrin intoxication. Our results showed that $S$. platensis slightly increased CAT activity with heavy metals. Similar results were obtained by Amer (2016) who reported that CAT activity increased in $O$. niloticus with $S$. platensis supplementation. Bangeppagari et al. (2014) stated that Spirulina enhanced antioxidant enzymes and reduced the lead toxicity in the fresh water fish Labeo rohita. Furthermore, Kim et al. (2013) indicated that Spirulina supplements improved the activities of antioxidant enzymes of fish through inhibiting the formation of reactive oxygen species.

\section{Conclusion}

Our results confirmed the success of S. platensis as a good choice and a better alternative source of protein in fish feed with lots of beneficial effects on the growth performance under normal conditions and as well as the growth performance, growth-related genes expression 
in $O$. niloticus fish against the toxic impact of heavy metals compared to C. vulgaris. Moreover, C. vulgaris and $S$. platensis modulated heavy metals-induced oxidative stress.

\section{Ethical Statement}

The study was approved by the Committee on the Ethics of the Theodor Bilharz Research Institute (TBRI) and institutional guidelines for the care and use of animals.

\section{Funding Information}

The authors received no specific funding for this work.

\section{Author Contribution}

HAS and HMME conceived and designed the study. HAS, HSG, HMME, AA, WAM and HO performed the experiments. HAS, HMME and $\mathrm{HO}$ analyzed and interpreted the data. HAS, HMME and HO wrote the first draft of the manuscript. HAS revised the manuscript and formulated the final version. All authors read and approved the final manuscript.

\section{Conflict of Interest}

The authors declare that they have no known competing financial or non-financial, professional, or personal conflicts that could have appeared to influence the work reported in this paper.

\section{Acknowledgements}

Not applicable.

\section{References}

Abdelhamid, F.M., Elshopakey, G.E., \& Aziza, A.E. (2020). Ameliorative effects of dietary Chlorella vulgaris and beta-glucan against diazinon-induced toxicity in Nile tilapia (Oreochromis niloticus). Fish and Shellfish Immunology, 96, 213-222.

Abdelkhalek, N.K.M., Ghazy, E.W., \& Abdel-Daim, M.M. (2015). Pharmacodynamic interaction of Spirulina platensis and deltamethrin in freshwater fish Nile tilapia, Oreochromis niloticus: impact on lipid peroxidation and oxidative stress. Environmental Science and Pollution Research, 22, 3023-3031. https://doi.org/10.1007/s11356-0143578-0

Abdel-Tawwab, M., El-Saadawy, H.A., El-Belbasi, H.I., Abd ElHameed, S.A.A. \& Attia, A.A. (2021). Dietary spirulina (Arthrospira platenesis) mitigated the adverse effects of imidacloprid insecticide on the growth performance, haemato-biochemical, antioxidant, and immune responses of Nile tilapia. Comparative Biochemistry and Physiology, Part C, 247, 1-9.

https://doi:10.1016/j.cbpc.2021.109067
Abdulrahman, N.M., Abid, S.H., Khidir, A.A., Omer, B.B., Rasheed, D.B.H., \& BahaAlddin, L.H. (2018). Effect of adding microalgae Chlorella sp. on some biological parameters and proximate analysis of common carp Cyprinus Carpio L. Iranian Journal Veterinary Medicine, 12(3), 199-205.

Aebi, H. (1984). Catalase in vitro. Methods in Enzymology, 105, 121-126.

Alalwan, H.A., Kadhom, M.A., \& Alminshid, A.H. (2020). Removal of heavy metals from wastewater using agricultural by products. Journal of Water Supply: Research and Technology, 99-112.

Ali, H., Khan, E., \& Ilahi, I. (2019). Environmental Chemistry and ecotoxicology of hazardous heavy metals: Environmental persistence, toxicity, and bioaccumulation. Journal of Chemistry, 1-14. https://doi.org/10.1155/2019/6730305

Al-Zayat, A.M. (2019). Effect of various levels of Spirulina (Arthrospira platensis) as feed supplement on growth performance, feed utilization, immune response and hematology of the Nile tilapia (Oreochromis niloticus) fingerlings. Egyptian Journal of Aquatic Biology \& Fisheries, 23(3), 361-370.

Amer, S.A. (2016). Effect of Spirulina platensis as feed supplement on growth performance, immune response and antioxidant status of mono-sex Nile Tilapia (Oreochromis niloticus). Benha Veterinary Medical Journal, 30, 1-10. https://doi.org/10.21608/bvmj.2016.31332

Amin, A., El Asely, A., Abd El-Naby, A.S., Samir, F., El-Ashram, A., Sudhakaran, R., \& Dawood, M.A.O. (2019). Growth performance, intestinal histomorphology and growthrelated gene expression in response to dietary Ziziphus mauritiana in Nile tilapia (Oreochromis niloticus). Aquaculture, 512, 734301. https://doi.org/10.1016/j.734301

Andrade, L.M., Cristiano, J.A., Meriellen, D., Claudio, A.N., \& Maria, A.M. (2018). Chlorella and Spirulina microalgae as sources of functional foods, nutraceuticals and food supplements; an overview. MOJ Food Processing \& Technology, 6(1), 45-58.

AOAC (Association of Official Analytical Chemists) (1992). Official Methods of Analysis of the Association of Official Analytical Chemists, $14^{\text {th }}$ ed. AOAC, Arlington.p. 3413.

APHA (American Public Health Association), 2005. American Water Works Association: Standard methods for the examination of water and wastewater. New York.

Authman, M.M., Zaki, M.S., Khallaf, E.A., \& Abbas, H.H. (2015). Use of fish as bio-indicator of the effects of heavy metals pollution. Journal of Aquaculture Research and Development, 6, 1-13. https://doi.org/10.4172/2155-9546.1000328

Balami, S., Sharma, A., \& Karn, R. (2019). Significance of nutritional value of fish for human health. Malaysian Journal of Halal Research Journal (MJHR), 2(2), 32-34.

Bangeppagari, M., Gooty, J.M., Tirado, J.O., Mariadoss, S., Thangaswamy, S., Maddela, N.R., \& Ortiz, D.R. (2014) Therapeutic efficiency of Spirulina against lead acetate toxicity on the fresh water fish Labeo rohita. American Journal of Life Sciences, 2(6), 389-394.

Beckman, B.R. (2011). Perspectives on concordant and discordant relations between insulin-like growth factor 1 (IGF1) and growth in fishes. General and Comparative Endocrinology, 170, 233-252. 
Bekcan, S., Dogakaya, L., \& Cakirogullari, G.C. (2006). Growth and body composition of European catfish (Silurus glanis) fed diet containing different percentages of protein. The Israeli Journal of Aqauculture-Bamidgeh, 58(2), 137-142.

Benedetti, M., Vecchi, V., Barera, S., \& Dall'Osto, L. (2018). Biomass from microalgae: the potential of domestication towards sustainable biofactories.

Microbial Cell Factories, 17, 1-18. https://doi.org/10.1186/s12934-018-1019-3

Brown, M.E. (1957). Experimental studies physiology. Academic Press, New York. pp: 361-400.

Budi, R.M.S., Rahardja, B.S., \& Masithah, E.D. (2020). Potential concentration of heavy metal copper $(\mathrm{Cu})$ and microalgae growth Spirulina plantesis in culture media. $2^{\text {nd }}$ International Conference on Fisheries and Marine Science, 441, 1-6. doi:10.1088/1755-1315/441/1/012147

Castell, J.D., \& Tiews, K. (1980). Report of the EIFAC, IUNS and ICES working group on standardization of methodology in fish nutrition research. EIFAC Technical Paper No. 36, FAO, Rome, Italy, 1-24.

Cobbina, S.J., Xu, H., Zhao, T., Mao, G., Zhou, Z., Wu, X., Liu, H., Zou, Y., Wu, X., \& Yang, L. (2015). A multivariate assessment of innate immune related gene expressions due to exposure to low concentration individual and mixtures of four kinds of heavy metals on zebrafish (Danio rerio) embryos. Fish and Shellfish Immunology, 47, 1032-1042.

Dawood, A.O.M. (2017). Feed additives to increase plant protein substitution in aquafeeds. EC Nutrition 9.5, 216 220.

De Chavez, P.L.C., \& Bolivar, R.B. (2018). Spirulina platensis as an alternative protein source for the African catfish Clarias gariepinus. AACL Bioflux, 11, 481-494.

El-Mezayen, M.M., Rueda-Roa, D.T., Essa, M.A., Muller-Karger, F.E., \& Elghobashy, A.E. (2018). Water quality observations in the marine aquaculture complex of the Deeba Triangle, Lake Manzala, Egyptian Mediterranean coast. Environmental Monitoring and Assessment, 190, 436 https://doi.org/10.1007/s10661-018-6800-6

Eyckmans, M., Celis, N., Horemans, N., Blust, R., \& De Boeck, G. (2011). Exposure to waterborne copper reveals differences in oxidative stress response in three freshwater fish species, Aquatic Toxicology, 103, 112120.

Goher, M.E., Abd El-Monem, A.M., Abdel-Satar, A.M., Ali, M.H., Hussian, A.M., \& Napiórkowska-Krzebietke, A. (2016). Biosorption of some toxic metals from aqueous solution using non-living algal cells of Chlorella vulgaris. Journal of Elementology, 21(3), 703-714. https://doi.org/10.5601/jelem.2015.20.4.1037

Hamed, M., Soliman, H.A.M., \& Sayed, A.E.D.H. (2019). Ameliorative effect of Spirulina platensis against lead nitrate-induced cytotoxicity and genotoxicity in catfish Clarias gariepinus. Environmental Science and Pollution Research, 26, 20610-20618.

Han, P., Lu, Q., Fan, L., \& Zhou, W. (2019). A Review on the use of microalgae for sustainable aquaculture. Applied Sciences, 9, 1-20. doi:10.3390/app9112377

Hua, K., Cobcroft, J.M., Cole, A., Condon, K., Jerry, D.R., Mangott, A., Praeger, C., Vucko, M.J., Zeng, C., Zenger, K., \& Strugnell, J.M. (2019). The future of aquatic protein: implications for protein sources in aquaculture diets. One Earth, 1(3), 316-329.
Ibrahem, M.D., Mohamed, M.F., \& Ibrahim, M.A. (2013). The role of Spirulina platensis (Arthrospira platensis) in growth and immunity of Nile Tilapia (Oreochromis niloticus) and its resistance to bacterial infection. Journal of Agricultural Science, 5(6), 109-117.

Javed, M., \& Usmani, N. (2019). An overview of the adverse effects of heavy metal contamination on fish health. Proceedings of the National Academy of Sciences, India Section B: Biological Sciences, 89(2), 389-403. https://doi.org/10.1007/s40011-017-0875-7

Jönsson, E. (2013). The role of ghrelin in energy balance regulation in fish. General and Comparative Endocrinology, 187, 79-85.

Jung, F., Krüger-Genge, A., Waldeckc, P., \& Küpper, J.H. (2019). Spirulina platensis, a super food? Journal of Cellular Biotechnology, 5, 43-54. https://doi.org/10.3233/JCB189012.

Khani, M., Soltani, M., Shamsaie, M.M., Foroudi, F., \& Ghaeni, M. (2017). The effects of Chlorella vulgaris supplementation on growth performance, blood characteristics and digestive enzymes in Koi (Cyprinus carpio). Iranian Journal of Fisheries Sciences, 16(2), 832843.

Kim, S.S., Rahimnejad, S., Kim, K.W., \& Lee, K.J. (2013). Partial replacement of fish meal with Spirulina pacifica in diets for parrot fish (Oplegnathus fasciatus). Turkish Journal of Fisheries and Aquatic Sciences, 13, 197-204.

Kumar, K.S., Dahms, H., Won, E., Lee, J., \& Shin, K. (2015). Microalgae - A promising tool for heavy metal remediation. Ecotoxicology and Environmental Safety, 113, 329-352.

Lee, J., Choi, H., Hwang, U., Kang, J., Kang, Y.J., Kim, K.I., \& Kim, J. (2019). Toxic effects of lead exposure on bioaccumulation, oxidative stress, neurotoxicity, and immune responses in fish: A review. Environmental Toxicology and Pharmacology, 1-24. https://doi.org/10.1016/j.etap.2019.03.010

Liu, C.Z., He, A.Y., Ning, L.J., Luo, Y., Li, D.L., Zhang, M.L., Chen, L.Q., \& Du, Z.Y. (2018). Leptin selectively regulates nutrients metabolism in Nile tilapia fed on high carbohydrate or high fat diet. Frontiers in Endocrinology, 9. https://doi.org/10.3389/fendo.2108.00574

Mahmoud, M.M.A., El-Lamie, M.M.M., Kilany, O.E., \& Dessouki. A.A. (2018). Spirulina (Arthrospira platensis) supplementation improves growth performance, feed utilization, immune response, and relieves oxidative stress in Nile tilapia (Oreochromis niloticus) challenged with Pseudomonas fluorescens. Fish and Shellfish Immunology, 72, 291-300. https://doi.org/10.1016/j.fsi.2017.11.006

Mehmood, M.A., Qadri, H., Bhat, R.A., Rashid, A., Ganie, S.A., Dar, G.H., \& Shafiq, R. (2019). Heavy metal contamination in two commercial fish species of a transHimalayan freshwater ecosystem. Environmental Monitoring and Assessment, 191 (2), 1-16. https:// doi.org/10.1007/s10661-019-7245-2.

Mohanty, D., \& Samanta, L. (2018). Dietary supplementation of Spirulina ameliorates iron induced oxidative stress in Indian knife fish Notopterus Notopterus, Environmental Toxicology and Pharmacology, 61, 71-78, https://doi.org/10.1016/j.etap.2018.05.007.

Nishikimi, M., Roa, N.A., \& Yogi, K. (1972). The occurrence of superoxide anion in the reaction of reduced phenazine methosulfate and molecular oxygen. Biochemical and Biophysical Research Communications, 46(2), 849-854. 
Nofal, M.I., Zaki, V.H., Ahmed, N.A.S., Abed-Aziz A.F., \& Rashad, M.M. (2019). Effects of heavy metal pollution on Nile tilapia in manzala farm: oxidative stress biomarkers and histopathological findings. International Journal of Fisheries and Aquatic Studies, 7(5), 315-328.

Nogueira, S.M.S., Junior, J.S., Maia, H.D., Saboya, J.P.S. \& Farias, W.R.L. (2018). Use of Spirulina platensis in treatment of fish farming wastewater. Revista Ciência Agronômica, 49(4), 599-606.

NRC (1993). Nutrition requirements of fish. National Research Council National. Academy Press, Washington, D. C. USA. pp. 114.

OECD (2012). Validation Report (Phase 2) for the Zebrafish Embryo Toxicity Test: Part I 6 and Part II. Series on Testing and Assessment No. 179, OECD, Paris.

Padrilah, S.N., Sabullah, M.K., Abd Shukor, M.Y., Yasid, N.A., Shamaan, N.A., \& Ahmad, S.A. (2018). Toxicity effects of fish histopathology on copper accumulation. Journal of Tropical Agricultural Science, 41 (2), 519-540.

Paglia, D.E. \& Valentine, W.N. (1967). Studies on the quantitative and qualitative characterization of erythrocyte glutathione peroxidase. Journal of Laboratory and Clinical Medicine, 70(1), 158-169.

Prabu, E., Rajagopalsamy, C.B.T., Ahilan, B., Jeevagan, I.J.M.A., \& Renuhadevi, M. (2020). Tilapia - An excellent candidate species for world aquaculture: A review. Annual Research \& Review in Biology, 1-15.

Promya, J., \& Chitmanat, C. (2011). The effects of Spirulina platensis and Cladophora algae on the growth performance meat quality and immunity stimulating capacity of the African sharptooth catfish (Clarias gariepinus). International Journal of Agriculture and Biology, 13(1), 77-82.

Radhakrishnan, S., Bhavan, P.S., Seenivasan, C., \& Muralisankar, T. (2017). Nutritional profile of Spirulina platensis, Chlorella vulgaris and Azolla pinnata to novel protein source for aquaculture feed formulation. Austin Journal of Aquaculture and Marine Biology, 2(1), 1-8.

Rafael, S.C.B., Daniel, Y.S., Evandro, K.L., \& José, E.P.C. (2018). Digestibility and pricing of Chlorella sorokiniana meal for use in tilapia feeds. Scientia Agricola, 75(3), 184-190.

Rajeshkumar, S., \& Li, X. (2018). Bioaccumulation of heavy metals in fish species from the Meiliang Bay, Taihu Lake, China. Toxicological Research 5, 288-295. https://doi.org/10.1016/j.toxrep.2018.01.007

Roy, S.S., \& Pal, R. (2014). Microalgae in aquaculture: A review with special references to nutritional value and fish dietetics. Proceedings of the Zoological Society, https://doi.org/10.1007/s12595-013-0089-9.

Sayed, A.H., El-Sayed, Y.S., \& El-Far, A.H. (2017). Hepatoprotective efficacy of Spirulina platensis against lead-induced oxidative stress and genotoxicity in catfish, Clarias gariepinus. Ecotoxicology and Environmental Safety, 143, 344-350.

Sevcikova, M., Modra, H., Slaninova, A., \& Svobodova, Z. (2011). Metals as a cause of oxidative stress in fish: a review. Veterinární Medicína, 56(11), 537-546.

Shah, M.R., Lutzu, G.A., Alam, A.P., Sarker, M.K., Parsaeimehr, C.A., Liang, Y., \& Daroch, M. (2018). Microalgae in aqua feeds for a sustainable aquaculture industry. Journal of Applied Phycology, 30, 197-213.

Shams, A.S., Ahmed, M.E.S., El-Nahrawey, M.M., Abou-Aiana, R.M., \& Elsadany, A.Y. (2019). Effect of Chlorella vulgaris algae supplementation on growth performance of suckling Friesian calves.18. Egyptian Journal Nutrition and Feeds, 22(2), 45-56.

Sharma, A., Patni, B., Shankhdhar, D., \& Shankhdhar, S.C. (2013). Zinc-An indispensable micronutrient. Physiology and Molecular Biology of Plants, 19(1), 11-20.

Sheikhzadeh, N., Mousavi, S., Hamidian, G., Firouzamandi, M., Oushani, A.K., \& Mardani, K. (2019). Role of dietary Spirulina platensis in improving mucosal immune responses and disease resistance of rainbow trout (Oncorhynchus mykiss). Aquaculture, 510: 1-8.

Simanjuntak, S.B.I., Indarmawan, I., \& Wibowo, E.S. (2018). Impact of fed containing different levels of diets supplementation Spirulina platensis on growth, haematological, body composition and biochemical parameters, of Gurami (Osphronemus gouramy). Turkish Journal of Fisheries and Aquatic Sciences, 18, 681-690.

Teimouri, M., Amirkolaie, A.K., \& Yeganeh, S. (2013). Effect of Spirulina platensis meal as a feed supplement on growth performance and pigmentation of rainbow trout (Oncorhynchus mykiss). World Journal of Fish and Marine Sciences, 5(2), 194-202.

Teimouri, M., Yeganeh, S., Mianji, G.R., Najafi, M., \& Mahjoub, S. (2019). The effect of Spirulina platensis meal on antioxidant gene expression, total antioxidant capacity, and lipid peroxidation of rainbow trout (Oncorhynchus mykiss). Fish Physiology and Biochemistry, https://doi.org/10.1007/s10695-019-0608-3

Tripathy, A. (2016). Oxidative stress, reactive oxygen species (ROS) and antioxidative defense system, with special reference to fish. International Journal of Current Research in Biosciences and Plant Biology, 3(10), 79-89. http://dx.doi.org/10.20546/ijcrbp.2016.310.010

Won, E.T., Douros, J.D., Hurt, D.A., \& Borski, R.J. (2016). Leptin stimulates hepatic growth hormone receptor and insulin-like growth factor gene expression in a teleost fish, the hybrid striped bass, General and Comparative Endocrinology, http://dx.doi.org/10.1016/j.ygcen.2016.02.003

Zahran, E., Elbahnaswy, S., Risha, E., \& El-Matbouli, M. (2020). Antioxidative and immunoprotective potential of Chlorella vulgaris dietary supplementation against chlorpyrifos-induced toxicity in Nile tilapia. Fish Physiology and Biochemistry, 46, 1549-1560. https://doi.org/10.1007/s10695-020-00814-8

Zahran, E., \& Risha, E. (2014). Modulatory role of dietary Chlorella vulgaris powder against arsenic-induced immunotoxicity and oxidative stress in Nile tilapia (Oreochromis niloticus). Fish and Shellfish Immunology, 41, 654-662.

Zaynab, M., Al-Yahyai, R., Ameen, A., Sharif, Y., Ali, L., Fatima, M., Khan, K.A., \& Li, S. (2021). Health and environmental effects of heavy metals. Journal of King Saud University - Science, 34(1), 101653.

Zeinab, A.K., Aly, M.S., Faiza, A.K., \& Fatma, E.M. (2015). Effect of Spirulina platensis and Lactobacillus rhamnosus on growth and biochemical performance of Nile Tilapia (Oreochromis niloticus) fingerlings. International Journal of Current Microbiology and Applied Sciences, 4(4), 747763.

Zhiyou, F., Fengchang, W., Lulu, C., Bingbing, X., Chenglian, F., Yingchen, B., Haiqing, L., Siyang, S., John, P.G. \& Wenjing, G. (2016). Copper and zinc, but not other priority toxic metals, pose risks to native aquatic species in a large urban lake in Eastern China. Environmental Pollution, 219, 1069-1076. 